University for Business and Technology in Kosovo

UBT Knowledge Center

UBT International Conference

2015 UBT International Conference

Nov 7th, 9:00 AM - 5:00 PM

\title{
Ethics of Tax Evasion, The case of Albania
}

Emirjeta Kandri

University of New York in Tirana, emirjeta.kandri@hotmail.com

Agim Mamuti

University of New York in Tirana, agim.mamuti@yahoo.com

Follow this and additional works at: https://knowledgecenter.ubt-uni.net/conference

Part of the Business Commons

\section{Recommended Citation}

Kandri, Emirjeta and Mamuti, Agim, "Ethics of Tax Evasion, The case of Albania" (2015). UBT International Conference. 33.

https://knowledgecenter.ubt-uni.net/conference/2015/all-events/33

This Event is brought to you for free and open access by the Publication and Journals at UBT Knowledge Center. It has been accepted for inclusion in UBT International Conference by an authorized administrator of UBT Knowledge Center. For more information, please contact knowledge.center@ubt-uni.net. 


\title{
Ethics of Tax Evasion, The case of Albania
}

\author{
Emirjeta Kandri ${ }^{1}$, Agim Mamuti ${ }^{2}$ \\ ${ }^{1}$ Finance and Accounting, University of New York in Tirana, \\ ${ }^{2}$ Faculty of Business and Economics, University of New York in Tirana, \\ emirjeta.kandri@hotmail.com¹,agim.mamuti@yahoo.com²
}

\begin{abstract}
Tax evasion and the ethics about it are widely discussed topics nowadays and they have revived a lot of debates among ethics analysts or government representatives and business mangers or owners. The first ones argue that it is unethical hiding revenues to avoid taxes, since they are one of the ways business owners contribute to their proper countries in order for the society of that country to benefit from those. On the other hand, businessmen argue that they already pay too much tax and do philanthropic donations, so there is no reason for them to feel they should pay more since they already contribute to the society. But what is tax evasion? Is tax evasion ethical or justifiable? Why would owners of huge businesses avoid tax even though they already have too much money in their bank accounts? Why would random people avoid taxes, even though the sum they have to pay is not too big to handle? How does it work for Albania? This paper gives some answers to the above raised questions. For this purpose, a questionnaire was prepared and filled by 200 students of the University of New York in Tirana (UNYT).
\end{abstract}

Keywords: tax, tax evasion, ethics, government, taxpayers

\section{Introduction}

Corporations give a huge importance to the maximizing of costs and minimizing of profits in order to pay fewer taxes to the state. Compromising accounts and financial instruments to reach this goal is considered a good governance and is part of a company's tax planning. While these corporations plan on how much tax they are going to pay at the end of the year, there have been built several schemes to make this plans.

First of all, it is important to understand there is a difference between tax evasion and tax avoidance. Tax evasion is against the law, but tax avoidance is a bit like a grey space since the state itself has issued laws to allow it. Some of the ways you can avoid taxes legally are: make a donation; appealing to your municipality's tax authorities to lower your properties value since it would reduce your real estate tax; consider using tax credits by installing energy-efficient machines in your home; buy a home rather than renting one since there are deducts with mortgages and interests you have to pay etc.

\section{Literature Review}

Although there have been made many studies regarding tax compliance, not many of them have been focused on codes of ethics. Tax compliance is mainly seen from financial and economic point of view, rather then psychological or philosophical point of view. One of the most important and rare documents regarding the ethics of tax evasion was a doctoral thesis written by Martin Crowe (1944). This thesis covered the moral point of view of paying taxes to the government. After that there have been several articles including some information about ethics. This paper is mostly focused on Crowe's writing especially on the making of the questionnaire and on McGee (1999) articles related to secular views on tax evasion. 


\section{Some tax avoidance schemes}

As far as it concerns to the tax evasion schemes there are as following: double-dutch-Irish sandwich; involvement of several borrowings that companies never pay; establishing the company in a tax haven country; not declaring the real number of sales etc.

Huge companies save billions of dollars while regularly hiding their real profit through these schemes and other sophisticated ones. They claim that they have already contributed to much to the society since they have employed a large number of people and help that part of the population which is more needy. Moreover, they think that the government should use a tax scheme, whichfavors those who have money, since they can spread their money to the society through expanding their staff. Numerous companies and people who have regular yearly income refuse to pay taxes because they think their government is corrupted or their country might be at war and they do not approve it. But, there are numerous debates going on whether tax evasion is really ethical or not.

Businessmen think that the governments should favor these kinds of companies or corporations since they are the ones that give jobs, increasing the welfare of a country. On the other hand, this does not make tax evasion morally right. Hiding profits and avoiding taxes means having less investment on hospitals, schools, military public areas etc. If none of us paid any taxes we would be living in tribes, uneducated, without any health care and unprotected. Even if one country is at war, fewer taxes would not cut off as much military budget as people think, it would rather cut off public spending on the goods that government offers to its people. In the case of corrupted governments the case becomes more complex since the taxpayers have lost faith that the government will spend this money for the people, rather then to meet their members needs. Still, there will be public investments done. In one way or other citizens will still benefit from these contributions they give for living in a certain country.

\section{Nordic Countries Tax Systems}

In these times of crisis, every citizen would like to be living in Norway, Sweden, Germany, Denmark or Finland. Little do they know that most of these countries have applied progressive taxing scheme where: Norway-an corporate tax is $27 \%$, its maximum income tax rate is $47.2 \%$ and standard VAT rate is $25 \%$; Swedish corporate tax is $22 \%$, its maximum income tax rate is $56.6 \%$ and standard VAT rate is $25 \%$; German corporate tax is $30.175 \%$, its maximum income tax rate is $45 \%$ and standard VAT rate is $19 \%$; Danish corporate tax is $22 \%$, its maximum income tax rate is $55.56 \%$ and standard VAT rate is $25 \%$ and Finish corporate tax is $20 \%$, its maximum income tax rate is $53 \%$ and standard VAT rate is $24 \%$. Meanwhile these rates in Albania fall to: corporate tax equal to $10 \%$, maximum income tax rate equal to $10 \%$ and standard VAT rate equal to $20 \%$. Having said all the numbers and having read information about the welfare of these countries, my opinion is it is pretty clear the difference and the cause of it.

\section{Albanian Case}

As far as it concerns to the Albanian case, the evasion is high and the reasons are pretty simple. Being a communist society for more than half a century, Albanians rely their hope and profits on the state only. This affects both sides of the coin: most of the citizens are used to the state providing jobs and pensions for them while only paying few taxes and governors are used to manipulate the economy as they will. This is a vicious circle in which we have been coming around for the past twenty years and still have not come to an end. Corruption is the first cause that people do not want to pay tax to the government. They say that public investments are very few and have lost faith for new ones. On the other hand, government comes with different projects on public investment, which they cannot apply because they do not collect enough taxes to have enough money. 


\section{Research Methodology}

In support to the research purposes, a questionnaire was prepared (see Appendix 1), which was addressed to 200 students of the University of New York in Tirana, most of which are finance or business major students. The questions were related to Crowe's famous arguments regarding tax evasion and an addition of three questions that cover the three new approaches. The evaluation was done 1-5 for each question.

Also, three hypotheses were built in order to have more concrete results off of this questionnaire:

I. If the average score for all 18 questions is between 0.5 and 0.9 the random student would think that tax evasion is some times ethical;

II. If the question related to the government being corrupted gets a score higher than 750 , the random student thinks tax evasion is ethical when the government is corrupted;

III. If women scores are lower than men scores, women are more opposed to tax evasion than the other gender.

\section{Research results by gender:}

This questionnaire was filled by 200 hundred students, 94 of which were male students and 106 were female students. When the word ethics was mentioned, it drew more the attention of the latest. The male students saw this issue as more of a grey space and were more flexible regarding the ethics related to tax evasion.

Table 1 Demographic data

\begin{tabular}{lll}
\hline Male Students & 94 & 8429 \\
\hline Female Students & 106 & 6345 \\
Total & 200 & 14774 \\
\hline
\end{tabular}

Source: Authors

Table 2 Research results by major

Finance $\quad 83$

\begin{tabular}{|l|l|}
\hline Business Administration & 49 \\
\hline Business Management & 22 \\
\hline Accounting & 4 \\
\hline Law & 35 \\
\hline Psychology & 7 \\
\hline Total & 200 \\
\hline
\end{tabular}

Source: Authors

The students that filled the questionnaires were of different majors. More precisely, 83 were finance major students; 49 were business administration students; 22 were business management students; 4 were accounting students and 7 were psychology students. One interesting thing about this was the fact that students put different emphasis on the questions and this process was mostly related to their 
major. For example, business management students were more flexible to tax evasion if the tax system was considered to be unfair while psychology major students did not think evading taxes was such a big deal in cases where people felt discriminated by their state.

\section{Conclusion}

The first hypothesis cannot be rejected; the random student thinks that sometimes tax evasion is ethical. The second hypothesis cannot be rejected neither. The third hypothesis will be rejected; men are more tax opposed than women.

As we observed, almost all of the students relate high tax rates, the wasting of the money, lack of the ability to pay taxes and political discrimination with tax evasion being fair. This kind of state of mind of Albanians results in a tax evasion of around 36.3 million US dollars per year. This might not be a significant number for other countries, but for Albania it is a huge number of taxes and investments being left out.

Lately, there has been placed a new taxation scheme for corporations. It is called progressive tax and it is expected that it enable the government collect more tax regarding to profits of corporations. Compared to the previous scheme, flat tax, people were relatively upset that the government decided to apply the new scheme. According to the government, this kind of tax collects more money from those who win more and it enables the implementation of more public projects. But those who are more affected from this kind of scheme find it absurd to pay more than they used to. They claim that the money they get is the result of hard working and find it difficult to share their profits with people who work less and winless.

According to financial data retrieved from the Albanian Ministry of Finances, the implementation of new tax schemes does enable the government collect more taxes, but that would be for the first year only. During the upcoming years, the government collects less until it reaches a point where it collects less than the last year the old tax scheme was applied.

Having it all said, tax evasion is not a matter of state financial policies rather then a society's principles and morals. Nevertheless, it may never be addressed as an ethical deed rather than lack of will to contribute to the society you live in.

\section{References}

1. Crowe, M. T. (1944). 'The Moral Obligation of Paying Just Taxes', The Catholic University of America Studies in Sacred Theology No. 84.

2. McGee, R. W., Nickerson, I. and Fees, W. (2005). 'When Is Tax Evasion Ethically Justifiable? A Survey of German Opinion.' Proceedings of the Academy of Legal, Ethical and Regulatory 19 Issues, V ol.9, No. 2, pp. 35-38, Las V egas, October 12-15 www.alliedacademies.org/pdf/vegas05/paleri-9-2.pdf .

3. Murtuza, A. and Ghazanfar, S.M. (1998). 'Taxation as a Form of Worship: Exploring the Nature of Zakat', Journal of Accounting, Ethics \& Public Policy, 1(2): 134-161, reprinted in R. W. McGee (ed.), The Ethics of Tax Evasion, Dumont, NJ: The Dumont Institute for Public Policy Research: Dumont, NJ, 1998, pp. 190-212.

4. McGee, R. W. (2005b). 'The Ethics of Tax Evasion: A Survey of Romanian Business Students and Faculty', Andreas School of Business Working Paper Series, Barry University, Miami Shores, FL 33161, USA, September. Reprinted at www.ssrn.com. Reprinted in R. W. McGee and G. G. Preobragenskaya, Accounting and Financial System Reform in Eastern Europe and Asia. Springer: New York, 2006.

5. McGee, R. W. (1994). 'Is Tax Evasion Unethical?' University of Kansas Law Review, 42(2): 411-435. Reprinted at http://ssrn.com/abstract=74420.

6. McGee, R. W. (1999a). 'Is It Unethical to Evade Taxes in an Evil or Corrupt State? A Look at Jewish, Christian, Muslim, Mormon and Baha'i Perspectives', Journal of Accounting, Ethics \& Public Policy, 2(1): 149-181. Reprinted at http://ssrn.com/abstract=251469. 
7. McGee, R. W. (1999b). 'Why People Evade Taxes in Armenia: A Look at an Ethical Issue Based on a Summary of Interviews', Journal of Accounting, Ethics \& Public Policy, 2(2): 408-416. Reprinted at http://ssrn.com/abstract $=242568$.

8. McGee, R. W. (1997). 'The Ethics of Tax Evasion and Trade Protectionism from an Islamic Perspective', Commentaries on Law \& Public Policy, 1: 250-262. Reprinted at http://ssrn.com/abstract $=461397$.

9. McGee, R. W. (Ed.). (1998a). The Ethics of Tax Evasion, Dumont, NJ: The Dumont Institute for Public Policy Research: Dumont, NJ.

10. McGee, R. W. (1998b). 'Christian Views on the Ethics of Tax Evasion', Journal of Accounting, Ethics \& Public Policy 1(2): 210-225. Reprinted at http://ssrn.com/abstract=461398. 